\title{
SLC6A8 Positive
}

National Cancer Institute

\section{Source}

National Cancer Institute. SLC6A8 Positive. NCI Thesaurus. Code C153433.

An indication that expression of SLC6A8 has been detected in a sample. 